\title{
МОДЕЛЬ ДЕТОНАЦИОННОГО ПРЯМОТОЧНОГО ВОЗДУШНО-РЕАКТИВНОГО ДВИГАТЕЛЯ: ИСПЫТАНИЯ В АЭРОДИНАМИЧЕСКОЙ ТРУБЕ ПРИ ОБТЕКАНИИ ВОЗДУШНЫМ ПОТОКОМ С ЧИСЛОМ МАХА 5,7 И ТЕМПЕРАТУРОЙ ТОРМОЖЕНИЯ $1500 \mathrm{~K}^{*}$
}

\author{
С. М. Фролов ${ }^{1}$, В. И. Звегинцев ${ }^{2}$, В. С. Иванов ${ }^{3}$, В. С. Аксёнов ${ }^{4}$, И. О. Шамшин ${ }^{5}$, \\ Д. А. Внучков ${ }^{6}$, Д. Г. Наливайченко ${ }^{7}$, А. А. Берлин ${ }^{8}$, В. М. Фомин ${ }^{9}$, А. Н. Шиплюк ${ }^{10}$, \\ Н. Н. Яковлев ${ }^{11}$
}

\begin{abstract}
Аннотация: Впервые экспериментально зарегистрирован режим непрерывно-детонационного горения водорода в кольцевой камере сгорания (KC) осесимметричной модели детонационного прямоточного воздушно-реактивного двигателя (ДПВРД) диаметром 310 мм и длиной 1050 мм в условиях обдува воздушным потоком с числом Маха 5,7 и температурой торможения $1500 \mathrm{~K}$ в импульсной аэродинамической трубе АТ-303 Института теоретической и прикладной механики им. С. А. Христиановича Сибирского отделения Российской академии наук (ИТПМ СО РАН). Тяга и удельный импульс модели двигателя составили 1550 Н и 3300 с. В отличие от традиционного ПВРД для ДПВРД характерны быстрое турбулентно-молекулярное смешение топливных компонентов и существенно более высокая скорость горения (в режиме самовоспламенения за бегущей ударной волной), а также пониженное внутреннее сопротивление КС (отсутствие уступов, каверн и др.). Ввиду высоких тяговых и массогабаритных характеристик ДПВРД можно рассматривать как альтернативу традиционной концепции ПВРД с дефлаграционным горением топлива.
\end{abstract}

Ключевые слова: детонационный прямоточный воздушно-реактивный двигатель; водород; огневые испытания; импульсная аэродинамическая труба; удельный импульс; тяга

\section{Литература}

1. Щетинков E.C. Способ работы прямоточного воздушно-реактивного двигателя // А.С. № 471815, F02K 7/10. Заявлено 16.04.57, № 464254/24-6. Опубл.
10.04.2000. Бюлл. № 10.

2. Фролов С.М., Звегинцев В.И., Иванов В.С., Аксенов В.С., Шамшин И.О., Внучков Д.А., Наливайченко Д. Г., Берлин А.А., Фомин В. М. Макет-демон-

\footnotetext{
* Работа выполнена при поддержке Российского научного фонда (грант № 14-13-00082П).

${ }^{1}$ Институт химической физики им. Н.Н. Семёнова Российской академии наук; Национальный исследовательский ядерный университет «МИФИ», smfrol@chph.ras.ru

${ }^{2}$ Институт теоретической и прикладной механики им. С. А. Христиановича Сибирского отделения Российской академии наук, zvegin@itam.nsc.ru

${ }^{3}$ Институт химической физики им. Н. Н. Семёнова Российской академии наук, ivanov.vls@gmail.com

${ }^{4}$ Институт химической физики им. Н. Н. Семёнова Российской академии наук; Национальный исследовательский ядерный университет «МИФИ», v.aksenov@mail.ru

${ }^{5}$ Институт химической физики им. Н.Н. Семёнова Российской академии наук; Национальный исследовательский ядерный университет «МИФИ», igor_shamshin@mail.ru

${ }^{6}$ Институт теоретической и прикладной механики им. С. А. Христиановича Сибирского отделения Российской академии наук, vnuchkov@itam.nsc.ru

${ }^{7}$ Институт теоретической и прикладной механики им. С. А. Христиановича Сибирского отделения Российской академии наук, denis@itam.nsc.ru

${ }^{8}$ Институт химической физики им. Н. Н. Семёнова Российской академии наук, berlin@chph.ras.ru

${ }^{9}$ Институт теоретической и прикладной механики им. С. А. Христиановича Сибирского отделения Российской академии наук, fomin@itam.nsc.ru

${ }^{10}$ Институт теоретической и прикладной механики им. С. А. Христиановича Сибирского отделения Российской академии наук, shiplyuk@itam.nsc.ru

${ }^{11}$ Тураевское машиностроительное конструкторское бюро «Союз», г. Лыткарино, amntksouyuz@mail.ru
} 
стратор непрерывно-детонационного прямоточного воздушно-реактивного двигателя. Результаты испытаний в аэродинамической трубе // Докл. РАН, 2017. T. 474. № 1. C. 51-55. doi: 10.7868/S0869565217130114.

3. Frolov S. M., Zvegintsev V.I., Ivanov V.S., Aksenov V.S., Shamshin I.O., Vnuchkov D.A., Nalivaichenko D.G., Berlin A.A., Fomin V.M. Wind tunnel tests of a hydrogen-fueled detonation ramjet model at approach air stream Mach numbers from 4 to 8 // Int. J. Hydrogen Energ., 2017. Vol. 42. P. 25401-25413. doi: 10.1016/j.ijhydene.2017.08.062.

4. Фролов С.М., Звегинцев В.И., Иванов В.С., Аксёнов В.С., Шамшин И.О., Внучков Д.А., Наливайченко Д. Г., Берлин А. А., Фомин В. М. Огневые испытания модели прямоточного воздушно-реактивного двигателя с детонационным горением водорода в аэродинамической трубе при числах Маха от 5 до 8 // Горение и взрыв, 2017. Т. 10. № 3. С. 26-35.

5. Звегинцев В. И. Газодинамические установки кратковременного действия. Ч. 1. Установки для научных исследований. - Новосибирск: Изд-во Параллель, 2014. С. 215-267.

6. Дубровский А.В., Иванов В.С., Зангиев А.Э., Фролов С.M. Трехмерное численное моделирование характеристик прямоточной воздушно-реактивной силовой установки с непрерывно-детонационной камерой сгорания в условиях сверхзвукового полета // Хим. физика, 2016. Т. 35. № 6. С. 49-63. doi: 10.7868/S0207401X16060042.

7. Фролов С. М., Аксенов В.С., Дубровский А. В. и др. Хемиионизационная и акустическая диагностика рабочего процесса в непрерывно-детонационных и импульсно-детонационных камерах сгорания // Докл. PAH, 2015. T. 465. № 1. С. 62-67. doi: 10.7868/ S0869565215310138.

8. Braun E. M., Lu F. K., Wilson D. R., Camberos J.A. Airbreathing rotating detonation wave engine cycle analysis // Aerosp. Sci. Technol., 2013. Vol. 27. P. 201-208.

9. Frolov S.M., Dubrovskii A.V., Ivanov V.S. Threedimensional numerical simulation of a continuously rotating detonation in the annular combustion chamber with a wide gap and separate delivery of fuel and oxidizer // Progress in propulsion physics / Eds. M. Calabro, L. DeLuca, S. Frolov, L. Galfetti, O. Haidn. - EUCASS advances in aerospace sciences book ser. - TORUS PRESS - EDP Sciences, 2016. Vol. 8. P. 375-388.

10. Vlasenko V.V., Shiryaeva A.A. Numerical simulation of nonstationary propagation of combustion along a duct with supersonic flow of a viscid gas // J. Aerospace Eng., 2012. Vol. 227. No. 3. P. 480-492.

Поступила в редакцию 11.01.18 


\title{
THE MODEL OF DETONATION RAMJET: FIRING TESTS IN A PULSED WIND TUNNEL WITH THE AIRFLOW OF MACH 5.7 AND STAGNATION TEMPERATURE $1500 \mathrm{~K}$
}

\author{
S. M. Frolov ${ }^{1,2}$, V. I. Zvegintsev ${ }^{3}$, V. S. Ivanov ${ }^{1}$, V. S. Aksenov ${ }^{1,2}$, I. O. Shamshin ${ }^{1,2}$, \\ D. A. Vnuchkov ${ }^{3}$, D. G. Nalivaichenko ${ }^{3}$, A. A. Berlin'1, V. M. Fomin ${ }^{3}$, A. N. Shiplyuk ${ }^{3}$, \\ and N. N. Yakovlev ${ }^{4}$
}

${ }^{1}$ N. N. Semenov Institute of Chemical Physics, Russian Academy of Sciences, 4 Kosygin Str., Moscow 119991, Russian Federation

${ }^{2}$ National Research Nuclear University MEPhI (Moscow Engineering Physics Institute), 31 Kashirskoe Sh., Moscow 115409, Russian Federation

${ }^{3}$ S. A. Khristianovich Institute of Theoretical and Applied Mechanics, Siberian Branch of the Russian Academy of Sciences, 4/1 Institutskaya Str., Novosibirsk 630090, Russian Federation

${ }^{4}$ Turaevo Machine-Building Design Bureau “Soyuz,” Lytkarino 140080, Moscow Region, Russian Federation

\begin{abstract}
The mode of continuous spinning detonation (CSD) of hydrogen in an annular combustor (AC) has been experimentally recorded for the first time in an axisymmetric model of a detonation ramjet with a diameter of $310 \mathrm{~mm}$ and a length of $1050 \mathrm{~mm}$ under airflow conditions with a Mach number of 5.7 and stagnation temperature of $1500 \mathrm{~K}$ in a pulsed wind tunnel AT-303 of ITAM SB RAS. The thrust and specific impulse of the ramjet model were $1550 \mathrm{~N}$ and $3300 \mathrm{~s}$, respectively. In contrast to the conventional ramjet operating on fuel deflagration, the operation process in the detonation ramjet is distinguished by a very rapid turbulent and molecular mixing of fuel components and a very high burning rate (combustion in the self-ignition mode behind the propagating shock wave), as well as very low internal drag (absence of ledges, cavities, etc.). In view of the high thrust and weight performance, the detonation ramjet can be considered as an alternative to the conventional concepts of a ramjet with fuel deflagration.
\end{abstract}

Keywords: detonation ramjet; hydrogen; firing tests; pulsed wind tunnel; specific impulse; thrust

\section{Acknowledgments}

The work was supported by the Russian Science Foundation (grant No. 14-13-00082P).

\section{References}

1. Shchetinkov, E. S. Priority date 16.04.1957. Method of ramjet operation. USSR Patent 471815, F02K 7/10. Published 10.04.2000. Bull. No. 10.

2. Frolov, S. M., V. I. Zvegintsev, V. S. Ivanov, V.S. Aksenov, I. O. Shamshin, D. A. Vnuchkov, D. G. Nalivaichenko, A. A. Berlin, and V. M. Fomin. 2017. Demonstrator of continuous-detonation air-breathing ramjet: Wind tunnel data. Dokl. Phys. Chem. 474(1):75-79. doi: 10.7868/S0869565217130114.

3. Frolov, S. M., V. I. Zvegintsev, V. S. Ivanov, V.S. Aksenov, I. O. Shamshin, D. A. Vnuchkov, D. G. Nalivaichenko, A. A. Berlin, and V. M. Fomin. 2017. Wind tunnel tests of a hydrogen-fueled detonation ramjet model at approach air stream Mach numbers from 4 to 8 . Int. J. Hydrogen Energ. 42:25401-25413. doi: 10.1016/ j.ijhydene.2017.08.062.

4. Frolov, S. M., V. I. Zvegintsev, V. S. Ivanov, V. S. Aksenov, I. O. Shamshin, D. A. Vnuchkov, D. G. Nalivaichenko, A.A. Berlin, and V.M. Fomin. 2017. Ognevye ispytaniya modeli pryamotochnogo vozdushno-reaktivnogo dvigatelya s detonatsionnym goreniem vodoroda $\mathrm{v}$ aerodinamicheskoy trube pri chislakh Makha ot 5 do 8 [Firing tests of the ramjet model with the detonative combustion of hydrogen in a wind tunnel at approach air stream Mach number from 5 to 8]. Goren. Vzryv (Mosk.) - Combustion and Explosion 10(3):26-35.

5. Zvegintsev, V. I. 2014. Gazodinamicheskie ustanovki kratkovremennogo deystviya. Ch. 1: Ustanovki dlya nauchnykh issledovaniy [Gasdynamic rigs of short-induced flow. Part 1. Rigs for scientific research]. Novosibirsk: Parallel Publs. 215-267.

6. Dubrovskii, A. V., V.S. Ivanov, A. E. Zangiev, and S. M. Frolov. 2016. Three-dimensional numerical simulation of the characteristics of a ramjet power plant with a continuous-detonation combustor in supersonic flight. Russ. J. Phys. Chem. B 10(3):469-482. doi: 10.7868/S0207401X16060042.

7. Frolov, S. M., V. S. Aksenov, A. V. Dubrovskii, A. E. Zangiev, V. S. Ivanov, S. N. Medvedev, and I. O. Shamshin. 2015. Chemiionization and acoustic diagnostics of the process in continuous- and pulse-detonation combus- 
tors. Dokl. Phys. Chem. 465(1):273-278. doi: 10.7868/ S0869565215310138.

8. Braun, E. M., F. K. Lu, D. R. Wilson, and J. A. Camberos. 2013. Airbreathing rotating detonation wave engine cycle analysis. Aerosp. Sci. Technol. 27:201-208.

9. Frolov, S. M., A. V. Dubrovskii, and V. S. Ivanov. 2016. Three-dimensional numerical simulation of a continuously rotating detonation in the annular combustion chamber with a wide gap and separate delivery of fuel and oxidizer.
Progress in propulsion physics. Eds. M. Calabro, L. DeLuca, S. Frolov, L. Galfetti, and O. Haidn. EUCASS advances in aerospace sciences book ser. TORUS PRESS EDP Sciences. 8:375-388.

10. Vlasenko, V. V., and A. A. Shiryaeva. 2012. Numerical simulation of nonstationary propagation of combustion along a duct with supersonic flow of a viscid gas. J. Aerospace Eng. 227(3):480-492.

Received January 11, 2018

\section{Contributors}

Frolov Sergey M. (b. 1959) - Doctor of Science in physics and mathematics, head of department, N. N. Semenov Institute of Chemical Physics, Russian Academy of Sciences, 4 Kosygin Str., Moscow 119991, Russian Federation; professor, National Research Nuclear University MEPhI (Moscow Engineering Physics Institute), 31 Kashirskoe Sh., Moscow 115409, Russian Federation; senior research scientist, Scientific Research Institute for System Studies, Russian Academy of Sciences, 36-1 Nakhimovskii Prosp., Moscow 117218, Russian Federation; smfrol@chph.ras.ru

Zvegintsev Valery I. (b. 1944) - Doctor of Science in technology, chief research scientist, S. A. Khristianovich Institute of Theoretical and Applied Mechanics, Siberian Branch of the Russian Academy of Sciences, 4/1 Institutskaya Str., Novosibirsk 630090, Russian Federation; zvegin@itam.nsc.ru

Ivanov Vladislav S. (b. 1986) - Candidate of Science in physics and mathematics, senior research scientist, N. N. Semenov Institute of Chemical Physics, Russian Academy of Sciences, 4 Kosygin Str., Moscow 119991, Russian Federation; ivanov.vls@gmail.com

Aksenov Victor S. (b. 1952) - Candidate of Science in physics and mathematics, senior research scientist, N. N. Semenov Institute of Chemical Physics, Russian Academy of Sciences, 4 Kosygin Str., Moscow 119991, Russian Federation; associate professor, National Research Nuclear University MEPhI (Moscow Engineering Physics Institute), 31 Kashirskoe Sh., Moscow 115409, Russian Federation; v.aksenov@mail.ru

Shamshin Igor O. (b. 1975) - Candidate of Science in physics and mathematics, senior research scientist, N. N. Semenov Institute of Chemical Physics, Russian Academy of Sciences, 4 Kosygin Str., Moscow 119991, Russian Federation; associate professor, National Research Nuclear University MEPhI (Moscow Engineering Physics Institute), 31 Kashirskoe Sh., Moscow 115409, Russian Federation; igor_shamshin@mail.ru

Vnuchkov Dmitry A. (b. 1980) - junior research scientist, S. A. Khristianovich Institute of Theoretical and Applied Mechanics, Siberian Branch of the Russian Academy of Sciences, 4/1 Institutskaya Str., Novosibirsk 630090, Russian Federation; vnuchkov@itam.nsc.ru

Nalivaichenko Denis G. (b. 1975) - Candidate of Science in technology, research scientist, S. A. Khristianovich Institute of Theoretical and Applied Mechanics, Siberian Branch of the Russian Academy of Sciences, 4/1 Institutskaya Str., Novosibirsk 630090, Russian Federation; denis@itam.nsc.ru

Berlin Alexander A. (b. 1940) - Academician of the Russian Academy of Sciences, Doctor of Science in chemistry, scientific director, N. N. Semenov Institute of Chemical Physics, Russian Academy of Sciences, 4 Kosygin Str., Moscow 119991, Russian Federation; berlin@chph.ras.ru

Fomin Vasily M. (b. 1940) - Academician of the Russian Academy of Sciences, Doctor of Science in physics and mathematics, professor, scientific supervisor, S. A. Khristianovich Institute of Theoretical and Applied Mechanics, Siberian Branch of the Russian Academy of Sciences, 4/1 Institutskaya Str., Novosibirsk 630090, Russian Federation; fomin@itam.nsc.ru

Shiplyuk Alexander N. (b. 1966) - Corresponding Member of the Russian Academy of Sciences, Doctor of Science in physics and mathematics, director, head of laboratory, S. A. Khristianovich Institute of Theoretical and Applied Mechanics, Siberian Branch of the Russian Academy of Sciences, 4/1 Institutskaya Str., Novosibirsk 630090, Russian Federation; shiplyuk@itam.nsc.ru

Yakovlev Nikolay N. (b. 1958) - Candidate of Science in physics and mathematics, project manager, Turaevo Machine-Building Design Bureau "Soyuz," Lytkarino 140080, Moscow Region, Russian Federation; amntksouyuz@mail.ru 